\title{
Vegetation Effects on Bacteria and Denitrifier Abundance in the Soils of Two Tidal Freshwater Wetlands in Virginia
}

\author{
Joseph C. Morina, ${ }^{1}$ Ember M. Morrissey, ${ }^{2}$ and Rima B. Franklin $\mathbb{D}^{1}$ \\ ${ }^{1}$ Department of Biology, Virginia Commonwealth University, Richmond, VA 23284, USA \\ ${ }^{2}$ Division of Plant and Soil Sciences, West Virginia University, Morgantown, WV 26505, USA \\ Correspondence should be addressed to Rima B. Franklin; rbfranklin@vcu.edu
}

Received 20 July 2018; Revised 25 September 2018; Accepted 11 November 2018; Published 4 December 2018

Academic Editor: Amaresh K. Nayak

Copyright (c) 2018 Joseph C. Morina et al. This is an open access article distributed under the Creative Commons Attribution License, which permits unrestricted use, distribution, and reproduction in any medium, provided the original work is properly cited.

\begin{abstract}
This study examined the abundance of bacteria and nirS-type denitrifiers associated with the rhizospheres of three emergent macrophyte species (Juncus effusus, Typha latifolia, and Peltandra virginica) to gain a greater understanding of plant-microbe interactions in wetland soils. Sampling of plant and soil properties was performed during the growing season (June) and following plant senescence (November) at two tidal freshwater wetlands. Quantitative polymerase chain reaction was used to determine the abundance of bacteria (16S rRNA) and nirS-type denitrifier genes from the rhizosphere and rhizoplane of each plant species and from nearby unvegetated soils. For bacteria, there was a positive rhizosphere effect that did not differ significantly across plant species. In contrast, significant differences in the abundance of nirS-type denitrifiers were observed across the plant species. Rhizosphere abundance was $\sim 2$-fold greater in Peltandra virginica and 4-fold greater in Typha latifolia compared to Juncus effusus. For both bacteria and nirS-type denitrifiers, plant effects were greater during the growing season, and abundance was highly correlated with soil $\mathrm{pH}$, moisture, and organic matter content. Overall, these results demonstrate plant effects on the rhizosphere microbial community can be species-specific and that there is a synergistic relationship between plant species and environmental conditions.
\end{abstract}

\section{Introduction}

Wetlands are ecosystems of intense biogeochemical transformations, especially in regard to nitrogen cycling. They are estimated to remove nearly $20 \%$ of anthropogenic nitrogen inputs worldwide $[1,2]$. One biogeochemical pathway of particular interest is denitrification, the stepwise reduction of nitrate $\left(\mathrm{NO}_{3}{ }^{-}\right)$or nitrite $\left(\mathrm{NO}_{2}^{-}\right)$to a $\mathrm{N}$-gas $\left(\mathrm{N}_{2} \mathrm{O}\right.$ or $\left.\mathrm{N}_{2}\right)$, which is then lost to the atmosphere. At the ecosystem level, rates of nitrogen removal have been linked with broad-scale changes in the size and composition of wetland plant communities [3-6]. Most prior efforts to disentangle this relationship have focused on how plant communities, sediment properties, and hydrology interact, and considerably less is known about the small-scale interactions that take place in the rhizosphere and rhizoplane of individual plants. However, such information is essential if we are to develop a predictive understanding of ecosystem nitrogen dynamics based on plant functional characteristics and plant community composition [7].

Wetland plants affect soil biogeochemistry in a variety of ways, including via direct effects on microbial communities and indirect effects mediated through changes in soil physicochemical properties [8, 9]. For example, organic carbon release via root exudates has been found to affect microbial community composition [10-13], influence overall microbial biomass [14-16], and enhance rates of microbial activity [17-19]. Since the quality and quantity of exudates can vary based on plant species, age, and health [20-22], this is one mechanism by which differences in plant community composition can influence microbial community structure and function. Similarly, microbial communities may respond to changes in redox conditions and oxygen availability that arise from differences in radial 
oxygen loss (ROL) associated with the varying root morphologies and gas transport systems of wetland plants $[3,23]$. These sorts of plant-mediated changes in carbon and oxygen availability are especially likely to affect denitrification, as it is primarily an anoxic heterotrophic process.

The metabolic pathways of denitrification are generally well studied. One of the most important steps is nitrite reduction, wherein $\mathrm{NO}_{2}{ }^{-}$is converted to a gaseous state as nitric oxide (NO). This step distinguishes denitrifiers from other nitrate-metabolizing microorganisms [24] and is regulated by the nitrite reductase enzyme. Denitrifiers carry one of two variants of the gene for nitrite reductase: nirS and nirK, which have both been used extensively as molecular markers for denitrifying bacteria [25-29]. These genes are functionally equivalent, exhibit differential habitat selection $[24,30,31]$, and, until very recently, were believed to be mutually exclusive [32]. The research presented here focuses on nirS, as it dominates our experimental system [33]. In particular, we studied how the abundance of bacteria and nirS-type denitrifiers changes in the rhizosphere and rhizoplane of three emergent freshwater macrophytes (Juncus effusus, Peltandra virginica, and Typha latifolia) in two tidal freshwater wetlands. Our main objectives were to determine the extent to which plant species enhanced nirS abundance and to evaluate whether plant effects on the microbial community are dependent upon soil conditions or season (i.e., growing season versus plant senescence).

\section{Materials and Methods}

2.1. Site Description. Two tidal freshwater wetlands were selected along the James River in the coastal plain of Virginia (USA), near Richmond. The first, referred to hereafter as "Rice," is a 28 -hectare wetland on the property of Virginia Commonwealth University's Rice Rivers Center $\left(37^{\circ} 19^{\prime} 38^{\prime \prime} \mathrm{N}, 77^{\circ} 12^{\prime} 13^{\prime \prime} \mathrm{W}\right)$. Originally forested wetland, Rice was dammed in the 1920s and used as a recreational lake for $\sim 80$ years. Wetland soil conditions and vegetation began to naturally return to the site following a partial breach of the earthen dam in 2007. The remainder of the dam was removed in 2010 as part of a targeted restoration effort, which fully restored tidal flow and natural hydrology to the wetland. The second site ("James") is a relatively undisturbed 1,700 ha wetland within the James River National Wildlife Refuge $\left(37^{\circ} 15^{\prime} 51.1^{\prime \prime} \mathrm{N}, 77^{\circ} 8^{\prime} 51.8^{\prime \prime} \mathrm{W}\right)$. Rice and James have similar soil texture, tidal regimes, and emergent macrophyte communities. Sampling was conducted at both sites during autumn senescence (November 2011) and during the peak of the growing season the following year (June 2012).

2.2. Experimental Design. This study focused on three macrophytes species, which differ in their root morphologies (Figure 1) and gas transport systems: Juncus effusus (common rush, hereafter Juncus), Typha latifolia (broadleaf cattail, hereafter Typha), and Peltandra virginica (arrow arum, hereafter Peltandra). Specifically, Typha has a rhizomatous root system while Juncas and Peltandra do not. Juncas utilizes a diffusive gas transport system [34] whereas Peltandra and Typha have pressured systems [35, 36], which tend to transport more oxygen belowground [37]. While rates of ROL can vary based on specific growth conditions, the potential of this particular Typha species to release oxygen is generally much higher than this Juncus [38].

For the November sampling, four replicate plants of each type were collected from each site. In June, five replicates were used. Only mature plants were included (based on height: Juncus: $\sim 100 \mathrm{~cm}$, Peltandra: $\sim 60 \mathrm{~cm}$, and Typha: $\sim 300 \mathrm{~cm}$ ). In the field, each plant and its associated soil were collected via coring $(25 \mathrm{~cm}$ diameter $)$ to a depth of $30 \mathrm{~cm}$, and intact plant-soil cores were transported upright to the laboratory in buckets. In addition, soil-only reference cores (8 $\mathrm{cm}$ diameter, $30 \mathrm{~cm}$ deep; 4 replicates in November and 5 in June) were collected from nearby unvegetated areas (i.e., no aboveground biomass within $30 \mathrm{~cm}$ ) and transported back to the laboratory on ice. At Rice, all plant and soil samples were collected within a $15 \times 30 \mathrm{~m}$ area of the wetland; at James, it was necessary to consider a slightly larger area $(30 \times 100 \mathrm{~m})$ in order to encounter all three plant types.

2.3. Soil Properties. Upon return to the lab, soil-only reference cores were extracted into air-tight plastic bags, sealed, and gently homogenized by hand. Soil redox potential and $\mathrm{pH}$ were immediately measured using a Hanna Combo probe (QA Supplies, Norfolk, VA, USA). Soil samples were then subdivided for future analysis of soil properties $(\sim 35 \mathrm{~g}$, stored at $4^{\circ} \mathrm{C}$ up to 1 week) and the associated microbial community ( $15 \mathrm{~g}$, stored at $-20^{\circ} \mathrm{C}$ up to one 1 month).

Soil moisture content was determined gravimetrically $\left(100 \pm 5^{\circ} \mathrm{C}\right.$ for $\left.72 \mathrm{~h}\right)$, and organic matter content (\%) was measured as the mass lost on ignition following combustion $\left(400^{\circ} \mathrm{C}\right.$ for $\left.12 \mathrm{~h}\right)$. Total carbon $(\mathrm{C})$ and nitrogen $(\mathrm{N})$ content were determined using a Perkin Elmer $\mathrm{CHNS} / \mathrm{O}$ Analyzer (Waltham, MA, USA) following the grinding and acidification of samples using $10 \%$ hydrochloric acid.

2.4. Rhizosphere and Rhizoplane Sampling. Immediately upon return to the lab, the intact root ball for each plant core was shaken gently by hand so that adhering bulk soil fell away. Rhizosphere samples were then obtained from the soil that remained immediately surrounding the roots of the plant. Five subsamples were collected along the depth of the core for each plant and pooled to yield a total of $\sim 35 \mathrm{~g}$ of soil per replicate plant. As with the unvegetated reference cores, the material was archived for analysis of soil properties and microbial communities.

For the June sampling event, rhizoplane samples were also collected from each plant for microbial community analyses. A modified version of the protocol outlined by Phillips et al. [39] was performed. First, several intact live roots were cut from the plant and shaken gently by hand to remove loose soil. These roots, along with any remaining root-bound soil, were then combined to generate one 


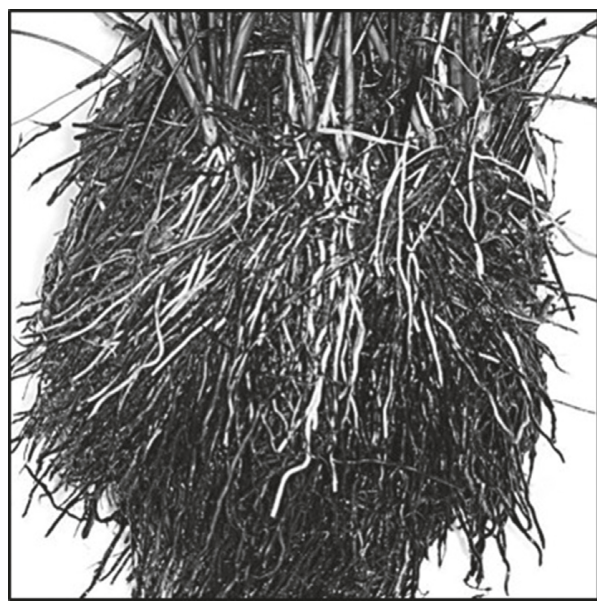

(a)

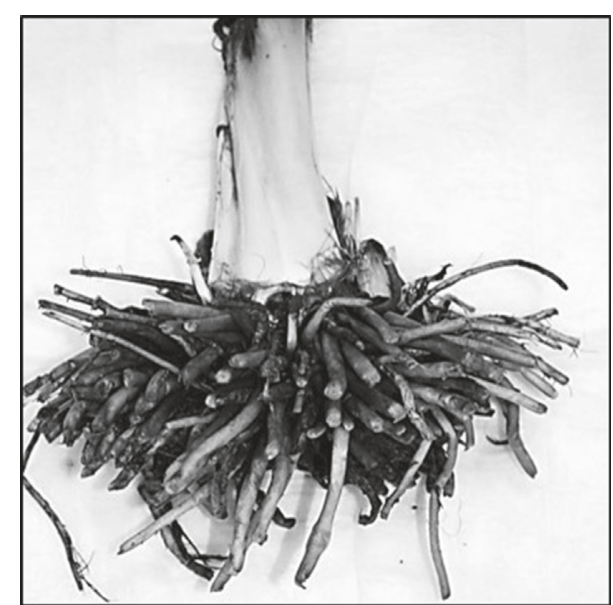

(b)

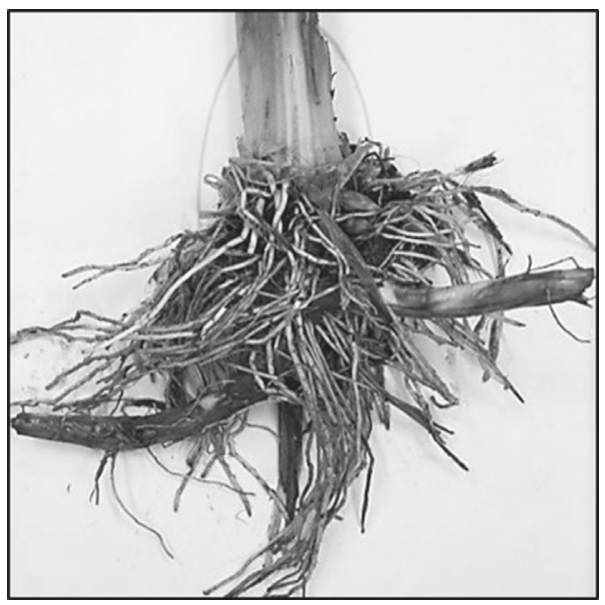

(c)

Figure 1: Photographs of root structure for (a) Juncus effusus, (b) Peltandra virginica, and (c) Typha latifolia.

aggregate sample per plant $(\sim 30 \mathrm{~g}$, minimum of 5 root strands), mixed with $200 \mathrm{ml}$ of sterile phosphate-buffered saline (PBS) buffer ( $\mathrm{pH}=7.4$ ) in a 250 -ml Erlenmeyer flask, and placed on a shaker table $(170 \mathrm{rpm}$ for $1 \mathrm{~h}$ ) to produce a soil slurry. An additional $40 \mathrm{ml}$ of PBS buffer was used to rinse the roots and flask, and the rinse was combined with the original slurry. The rhizoplane soil was then collected by centrifugation $(1100 \times \mathrm{g}, 10 \mathrm{~min})$, and pelleted soils were stored frozen for molecular genetic analysis $\left(-20^{\circ} \mathrm{C}\right.$ up to 1 month).

2.5. Plant Biomass. Plant biomass was only measured during the June sampling event; all data are reported as grams dry weight (DW) per plant. For belowground biomass, roots were harvested from each core, rinsed by hand, dried $\left(70^{\circ} \mathrm{C}\right.$ for $48 \mathrm{~h}$ ), and weighed. Aboveground biomass was estimated after sorting and drying $\left(100 \pm 5^{\circ} \mathrm{C}\right.$ for $\left.72 \mathrm{~h}\right)$ live material. Subsamples of the aboveground material were archived for subsequent analysis of $\mathrm{C}: \mathrm{N}$ of the leaf tissue.

2.6. Microbial Abundance. Whole-community DNA was extracted from $0.5 \mathrm{~g}$ subsamples of soil using MoBio
PowerSoil DNA Isolation Kit (Carlsbad, CA, USA) and then stored at $-20^{\circ} \mathrm{C}$. DNA extractions were verified using agarose gel electrophoresis; purity and concentration were determined using a Nanodrop ND-1000 (Thermo Scientific, Wilmington, DE, USA).

To estimate total bacterial abundance, quantitative polymerase chain reaction (qPCR) was performed targeting the $16 S$ rRNA gene with the Eub338 and Eub517 primers [40]. Genomic DNA from Escherichia coli (Strain \#11775; ATCC, Manassas, VA, USA) was used for the standard curve (average efficiency $\left.=98.8 \%, r^{2}=0.995\right)$. Reactions $(20 \mu \mathrm{l})$ were performed with $1.2 \mathrm{ng}$ template DNA and $0.1 \mu \mathrm{M}$ concentration of each primer; thermal cycling conditions were $95^{\circ} \mathrm{C}$ for $4 \mathrm{~min}$ followed by 40 cycles of $30 \mathrm{~s}$ at $95^{\circ} \mathrm{C}, 30 \mathrm{~s}$ at $55.5^{\circ} \mathrm{C}$, and $60 \mathrm{~s}$ at $72^{\circ} \mathrm{C}$.

A preliminary analysis using a subset of samples indicated nirK abundance (assessed via qPCR following Mosier and Francis [41]) was very low $\left(10^{1}-10^{3}\right.$ copies per $\mathrm{g}$ dry weight of soil) and showed no significant plant or site effects; consequently, our analyses focused on nirS. Those qPCRs were performed using nirS-specific primers $\mathrm{cd} 3 \mathrm{aF}$ and R3cd [26] and genomic DNA from Paracoccus denitrificans (ATCC Strain \#17741) for the standard curve 
(average efficiency $\left.=93.4 \%, r^{2}=0.991\right)$. Reactions $(20 \mu \mathrm{l})$ included $10 \mathrm{ng}$ of template DNA and $0.1 \mu \mathrm{m}$ concentrations of each primer; thermal cycling conditions were $95^{\circ} \mathrm{C}$ for $4 \mathrm{~min}$ followed by 50 cycles of $30 \mathrm{~s}$ at $95^{\circ} \mathrm{C}, 30 \mathrm{~s}$ at $56^{\circ} \mathrm{C}$, and $60 \mathrm{~s}$ at $72^{\circ} \mathrm{C}$.

All qPCR assays used the SsoAdvanced SYBR Green qPCR Supermix (BioRad, Hercules, CA, USA) and a BioRad CFX 96 Real-Time System. Data were analysed using BioRad CFX Manager (Version 2.1), and results were reported as the number of gene copies per $g$ dry weight of soil after averaging three technical replicates per sample.

2.7. Statistical Analyses. Shapiro-Wilks tests confirmed that data for all soil parameters and plant biomass metrics were normally distributed. $\log _{(10)}$ transformations were necessary for $16 S r R N A$ and nirS gene abundances prior to statistical analyses. To investigate main effects of site (Rice vs. James) and plant type (Juncus, Typha, and Peltandra), data were examined using a two-factor analysis of variance (ANOVA) applied to each sampling date (4 replicates for reference soil and each plant type in November, 5 of each in June). Whenever a significant interaction effect was obtained, separate single-factor ANOVAs were run to assess plant differences within sites, and $t$-tests were used to compare a given plant species across sites. Tukey's HSD was used for all post hoc comparisons.

To quantify the relative influence that each plant type had on gene abundance, a "plant-effect ratio" was calculated as the abundance in the rhizosphere (or rhizoplane) divided by abundance in the unvegetated reference soil. The null hypothesis of no plant effect predicts a ratio of one, wherein the proportion of the community that is bacteria (or nirS denitrifiers) is the same in the rhizosphere as in the bulk soil. Ratios greater than one represent enhanced abundance of the microbial group proximal to the plant roots, and ratios less than one indicate suppression. One-sample $t$-tests were used to determine when the plant-effect ratios were significantly different from one.

Lastly, stepwise multiple regression $(p$ entry $=0.10, p$ exclusion $=0.15, p$ for final inclusion $=0.05)$ was used to quantify the relationship between soil properties $(\mathrm{pH}$, redox, moisture, OM, and $\mathrm{C}: \mathrm{N}$ ) and microbial abundance in the rhizosphere. Because the extent and mechanism of any plant effects were expected to differ depending on season (i.e., November senescence vs. June growth), data for each sampling event were analysed separately. Equivalent analysis of rhizoplane abundance could not be conducted because comparable environmental data were not available. All statistical analyses were performed using SPSS (Version 21, IBM Corp., Armonk, NY, USA).

\section{Results}

3.1. Microbial Abundance in the Rhizosphere. Bacterial abundance in the rhizosphere ranged from $10^{7}$ to $10^{8} 16 \mathrm{~S}$ $r R N A$ gene copies per gDW of soil (Table 1). In November, no statistically significant differences due to either site or plant type were detected. In contrast, differences due to both factors were significant for June (two-factor ANOVA, all $p<0.001)$. We found bacteria abundance at that time to be lowest in the unvegetated soil (mean across both sites: 1.3 $\left.( \pm 0.4) \times 10^{7}\right), 2$ - to 3 -fold higher for Peltandra and Typha $\left(3.7( \pm 0.7) \times 10^{7}\right)$ and 7 -fold higher for Juncus $(8.4( \pm 2.0) \times$ $\left.10^{7}\right)$. Overall, bacterial abundances were greater at James than Rice by a factor of $\sim 1.5-2$.

The abundance of denitrifiers in the rhizosphere was lower than that for bacteria, ranging from $10^{6}$ to $10^{7}$ nirs gene copies per gDW of soil (Table 1). For both sampling events, a significant effect of the plant type was observed (all $p<0.001)$. Unvegetated soils consistently had the lowest abundance of nirS denitrifiers, followed by soil samples from the rhizosphere of Juncus and Peltandra ( 5-fold greater), and then soil samples from Typha ( $\sim 10$-fold greater overall). There was no site effect in November; however, in June, a significant site effect was observed $(p<0.001)$, wherein abundance was again higher at James than Rice.

3.2. Plant-Effect Ratios. Plant-effect ratios for rhizosphere samples from November (Figure 2(a)) indicate no consistent pattern of enhancement of bacteria abundance relative to the unvegetated soils (only the $t$-test for James-Peltandra was significant $(p<0.001))$. In contrast, plants sampled in June had significantly higher bacterial abundance (Figure 2(a)) in their rhizospheres compared to unvegetated soils by a factor of $\sim 2$ (all $p<0.04$, except Rice-Typha $p=0.14$ ). A two-factor ANOVA showed no differences in plant-effect ratio associated with the site or plant type.

For denitrifiers (Figure 2(b)), plant-effect ratios were significantly greater than 1 for Peltandra and Typha for both sites and sampling events (all $p \leq 0.001$ ). In November, denitrifier abundance was 2 to 3 times greater in the rhizosphere of these two plants compared to unvegetated soil, whereas the enrichment was 4 - to 8 -fold in June. For both sampling dates, the enrichment effect was significantly greater at Rice compared to James (site effect from twofactor ANOVA; November $p=0.05$, June $p<0.001$ ).

Effect ratios were also calculated for rhizoplane samples in June. For bacteria, the rhizoplane effect ratio was always greater than the rhizosphere effect ratio; this trend is evidenced by all points being above the 1:1 line in Figure 3(a). In the case of denitrifier abundance, rhizosphere and rhizoplane effect ratios were similar (along the 1:1 line in Figure 3(b)).

3.3. Plant Characteristics. Plant characteristics were assessed during the growing season (June), and significant differences were observed due to plant type but not site (Table 2). Specifically, the $\mathrm{C}: \mathrm{N}$ content of the aboveground vegetation of Juncus ( $45.5 \pm 7.4$, combining both sites) was higher than that of Peltandra $(22.0 \pm 2.0)$ and Typha $(25.8 \pm 2.0)$. Plant species also differed with respect to aboveground plant biomass (gDW per individual) wherein Peltandra $(53 \pm 11)$ and Typha $(71 \pm 5)$ had significantly less dry mass than Juncus $(135 \pm 35)$ across both sites. Similarly, belowground biomass (gDW per individual) differed across species but 
TABLE 1: Soil physicochemical properties and microbial abundance data reported as means and standard errors.

\begin{tabular}{|c|c|c|c|c|c|c|c|c|c|}
\hline Date & Site & Plant & $\begin{array}{c}\text { Soil moisture } \\
(\%)\end{array}$ & $\begin{array}{l}\text { Redox } \\
(\mathrm{mV})\end{array}$ & $\mathrm{pH}$ & $\begin{array}{c}\text { Organic matter } \\
(\%)\end{array}$ & $\begin{array}{l}\mathrm{C}: \mathrm{N} \\
\text { ratio }\end{array}$ & $\begin{array}{c}\text { Bacterial } \\
\text { abundance* }\end{array}$ & $\begin{array}{c}\text { Denitrifier } \\
\text { abundance* }\end{array}$ \\
\hline \multirow{10}{*}{ November 2011} & \multirow{5}{*}{ Rice } & Reference soil & $66(8)^{b}$ & $-15(3)^{b}$ & $6.6(0.5)$ & $16(4)^{\mathrm{B}}$ & $15.7(1.0)^{\mathrm{A}}$ & $230(74)$ & $9.0(3.5)^{\mathrm{C}}$ \\
\hline & & Juncus & $46(2)^{c}$ & $276(60)^{\mathrm{a}}$ & $6.9(0.3)$ & $6(1)^{\mathrm{C}}$ & $15.5(0.7)^{\mathrm{A}}$ & 378 (59) & $22.1(1.4)^{\mathrm{B}}$ \\
\hline & & Peltandra & $76(2)^{a b}$ & $-42(12)^{\mathrm{b}}$ & $7.3(0.5)$ & $21(1)^{\mathrm{A}}$ & $15.1(1.3)^{\mathrm{AB}}$ & $232(42)$ & $16.3(2.2)^{\mathrm{B}}$ \\
\hline & & Typha & $78(2)^{\mathrm{ab}}$ & $2(22)^{\mathrm{b}}$ & $7.8(0.1)$ & $25(2)^{\mathrm{A}}$ & $13.8(0.5)^{\mathrm{B}}$ & $417(81)$ & $42.0(6.5)^{\mathrm{A}}$ \\
\hline & & Overall & $67(4)$ & $55(36)$ & $7.2(0.2)^{\dagger}$ & $17(2)^{\dagger}$ & $15.0(0.4)$ & $314(37)$ & $22.3(3.6)$ \\
\hline & \multirow{5}{*}{ James } & Reference soil & $80(1)^{\mathrm{ab}}$ & 77 (17) & $6.0(0.1)$ & $18(2)^{\mathrm{B}}$ & $15.7(0.8)^{\mathrm{A}}$ & $160(40)$ & $4.8(0.6)^{\mathrm{C}}$ \\
\hline & & Juncus & $84(1)^{\mathrm{a}}$ & $88(34)$ & $6.1(0.1)$ & $15(2)^{C}$ & $16.3(0.4)^{\mathrm{A}}$ & $101(27)$ & $12.5(5.8)^{\mathrm{B}}$ \\
\hline & & Peltandra & $81(1)^{\mathrm{ab}}$ & $-3(25)$ & $5.8(0.1)$ & $26(2)^{\mathrm{A}}$ & $14.9(0.3)^{\mathrm{AB}}$ & $153(38)$ & $24.6(7.4)^{\mathrm{B}}$ \\
\hline & & Typha & $78(3)^{\mathrm{b}}$ & $-8(35)$ & $6.0(0.1)$ & $24(2)^{\mathrm{A}}$ & $13.1(0.6)^{\mathrm{B}}$ & $486(162)$ & $114.5(47.4)^{\mathrm{A}}$ \\
\hline & & Overall & $81(1)$ & $39(17)$ & $6.0(0.0)^{\ddagger}$ & $21(1)^{*}$ & $15.0(0.4)$ & $189(60)$ & $39.1(15.7)$ \\
\hline \multirow{10}{*}{ June 2012} & \multirow{6}{*}{ Rice } & Reference soil & $55(3)^{\mathrm{B}}$ & $2(40)^{\mathrm{B}}$ & $5.3(0.2)^{\mathrm{b}}$ & $13(1)^{\mathrm{A}}$ & $13.9(0.7)^{\mathrm{B}}$ & $5(1)^{\mathrm{C}}$ & $0.6(0.2)^{\mathrm{C}}$ \\
\hline & & Juncus & $39(6)^{\mathrm{C}}$ & $321(45)^{\mathrm{A}}$ & $4.8(0.1)^{\mathrm{c}}$ & $9(2)^{B}$ & $19.4(2.4)^{\mathrm{A}}$ & $39(13)^{\mathrm{A}}$ & $2.1(0.8)^{\mathrm{B}}$ \\
\hline & & Peltandra & $56(1)^{\mathrm{AB}}$ & $-29(34)^{\mathrm{B}}$ & $5.7(0.1)^{\mathrm{ab}}$ & $13(2)^{\mathrm{A}}$ & $15.6(0.6)^{\mathrm{B}}$ & $15(2)^{B}$ & $5.9(0.9)^{\mathrm{B}}$ \\
\hline & & Typha & $62(2)^{\mathrm{A}}$ & $16(40)^{\mathrm{B}}$ & $5.8(0.0)^{\mathrm{a}}$ & $14(1)^{\mathrm{A}}$ & $13.8(1.0)^{\mathrm{B}}$ & $13(4)^{\mathrm{B}}$ & $6.3(0.4)^{\mathrm{A}}$ \\
\hline & & Overall & $53(3)^{\dagger}$ & 77 (37) & $5.4(0.1)$ & $12(1)$ & $15.7(0.8)^{\dagger}$ & $18(4)^{\dagger}$ & $3.7(0.6)^{\dagger}$ \\
\hline & & Reference soil & $62(5)^{\mathrm{B}}$ & $-61(31)^{\mathrm{B}}$ & $6.2(0.1)^{b}$ & $15(2)^{\mathrm{A}}$ & $13.2(0.5)^{\mathrm{B}}$ & $21(7)^{\mathrm{C}}$ & $12.8(4.3)^{\mathrm{C}}$ \\
\hline & \multirow{4}{*}{ James } & Juncus & $37(3)^{\mathrm{C}}$ & $210(21)^{\mathrm{A}}$ & $6.6(0.1)^{\mathrm{a}}$ & $10(2)^{B}$ & $16.1(1.0)^{\mathrm{A}}$ & $129(25)^{\mathrm{A}}$ & $70.8(22.0)^{\mathrm{B}}$ \\
\hline & & Peltandra & $70(2)^{\mathrm{AB}}$ & $-37(20)^{\mathrm{B}}$ & $6.6(0.1)^{\mathrm{a}}$ & $24(2)^{\mathrm{A}}$ & $12.9(0.4)^{\mathrm{B}}$ & $63(11)^{\mathrm{B}}$ & $63.8(16.1)^{\mathrm{B}}$ \\
\hline & & Typha & $75(2)^{\mathrm{A}}$ & $-37(19)^{\mathrm{B}}$ & $6.7(0.1)^{\mathrm{a}}$ & $24(2)^{\mathrm{A}}$ & $12.4(0.3)^{\mathrm{B}}$ & $55(14)^{\mathrm{B}}$ & $65.6(20.2)^{\mathrm{A}}$ \\
\hline & & Overall & $61(4)^{\ddagger}$ & $11(26)$ & $6.5(0.1)$ & $18(2)$ & $13.6(0.4)^{\ddagger}$ & $67(12)^{\ddagger}$ & $53.2(9.5)^{\ddagger}$ \\
\hline
\end{tabular}

Each sampling date was analyzed using a two-factor ANOVA testing for site and plant effects. Whenever a significant site-by-plant interaction was obtained $(p \leq 0.05)$, each site was reanalyzed separately, and Tukey's HSD post hoc tests are reported using lowercase letters to distinguish plant effects at each location. In cases where the interaction effect was not significant, main effects are reported using uppercase letters (Tukey's) for differences across plant types, and ${ }_{\dagger / \neq}$ overall site effects. ${ }^{*}$ Units for abundance data are $\left(\times 10^{6}\right)$ gene copies gDW soil ${ }^{-1}$.

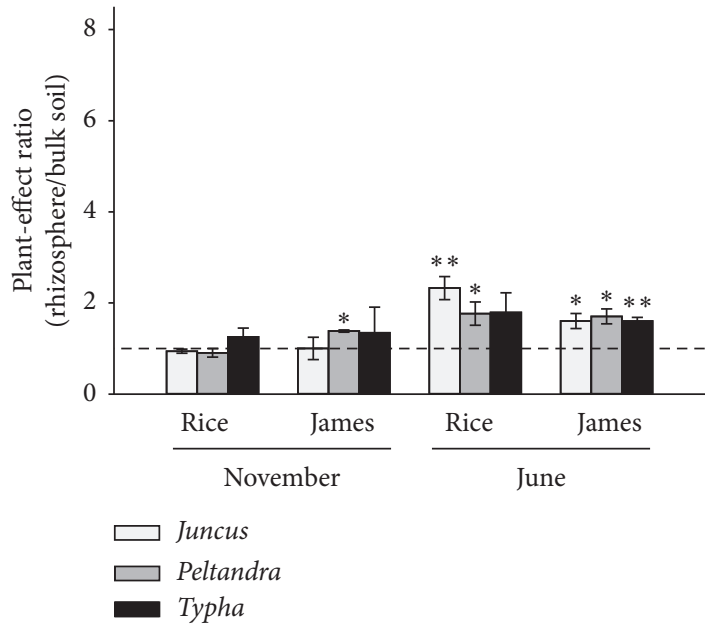

(a)

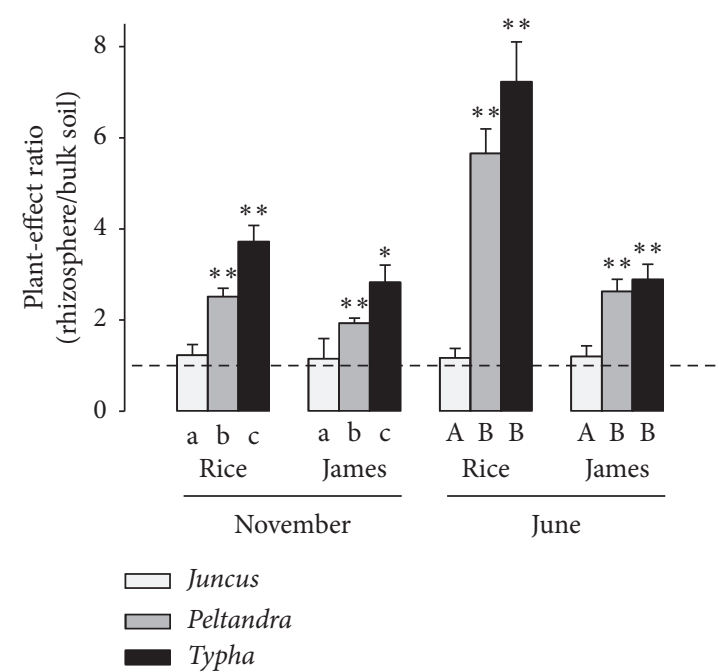

(b)

Figure 2: Plant-effect ratio for (a) bacteria and (b) denitrifier abundance associated with the rhizosphere of three plant species (Juncus effuses, Peltandra virginica, and Typha latifolia). Values are plotted as means and standard errors. A plant-effect ratio of "1" (dashed horizontal line) indicates that abundance in the rhizosphere samples was the same as abundance in the reference (unvegetated) soil. Bars with *(for $0.01 \leq$ $p<0.05$ ) and ${ }^{* *}$ (for $p<0.01$ ) above them indicate the period when rhizosphere samples had significantly greater abundance than reference soils as determined via $t$-test. For bacteria (a), two-factor ANOVA of the effect ratios found no significant plant or site effects for either sampling date. For denitrifiers (b), main effects of site and plant type were significant for both sampling dates. Results of Tukey's HSD post hoc tests comparing plant types are presented using letters beneath each bar (lowercase for November and uppercase for June).

not sites. Typha had significantly less root mass $(36 \pm 6)$ than Peltandra $(282 \pm 47)$ and Juncus $(237 \pm 38)$. The average belowground biomass for unvegetated reference soil was 0.6 $\pm 0.2 \mathrm{mgDW}$ root material per gDW of soil and did not differ across sites.
3.4. Soil Properties. For both sampling events, soil properties varied between sites and plant types (Table 1). In general, the lowest soil moisture values were associated with Juncus rhizosphere samples, and the wettest conditions were associated with Typha. The sole exception to this was at James 


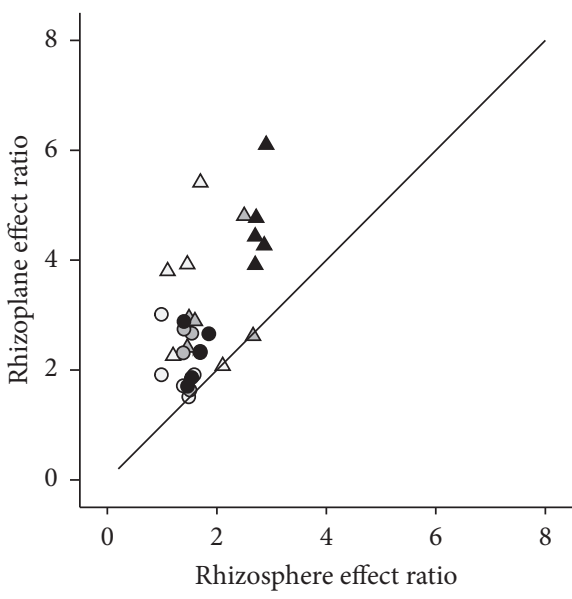
$\triangle$ Rice Juncus
$\triangle$ Rice Peltandra
- Rice Typha

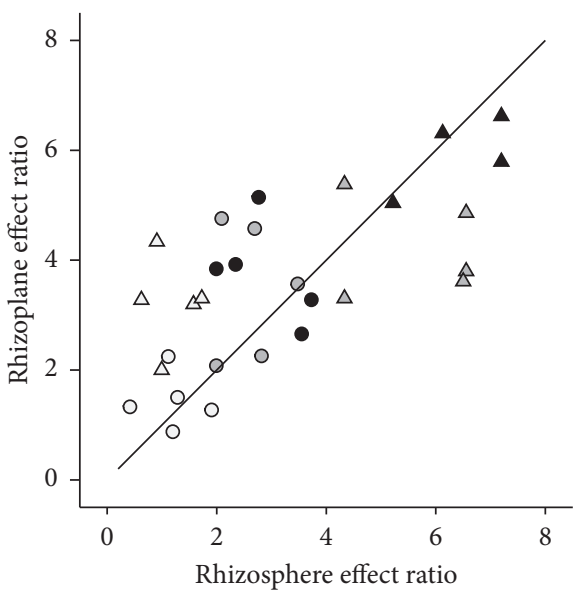
$\Delta$ Rice Juncus
- James Juncus
$\triangle$ Rice Peltandra
- James Peltandra
- Rice Typha
- James Typha

(a)

(b)

Figure 3: Plant-effect ratio for (a) bacterial and (b) denitrifier abundance associated with either the rhizosphere (X-axis) or rhizoplane ( $Y$ axis) samples collected in June. The solid lines represent the $1: 1$ relationship wherein the rhizosphere and rhizoplane effects are equal.

TABLE 2: Plant characteristics for June sampling reported as mean and standard errors.

\begin{tabular}{lcccc}
\hline Site & Plant & Root biomass $\left(\mathrm{gDW}\right.$ plant $\left.^{-1}\right)$ & Aboveground biomass $\left(\mathrm{gDW}\right.$ plant $\left.^{-1}\right)$ & C: $\mathrm{N}$ for aboveground biomass \\
\hline \multirow{4}{*}{ Rice } & Juncus & $235(72)^{\mathrm{A}}$ & $142(23)^{\mathrm{A}}$ & $54.6(11.8)^{\mathrm{A}}$ \\
& Peltandra & $193(49)^{\mathrm{A}}$ & $53(21)^{\mathrm{B}}$ & $18.9(1.8)^{\mathrm{B}}$ \\
& Typha & $41(6)^{\mathrm{B}}$ & $74(7)^{\mathrm{B}}$ & $27.4(3.5)^{\mathrm{B}}$ \\
\hline \multirow{2}{*}{ James } & Juncus & $238(39)^{\mathrm{A}}$ & $127(70)^{\mathrm{A}}$ & $36.4(7.2)^{\mathrm{A}}$ \\
& Peltandra & $372(60)^{\mathrm{A}}$ & $54(12)^{\mathrm{B}}$ & $25.1(2.6)^{\mathrm{B}}$ \\
& Typha & $32(10)^{\mathrm{B}}$ & $68(8)^{\mathrm{B}}$ & $24.2(2.2)^{\mathrm{B}}$ \\
\hline
\end{tabular}

Two-factor ANOVA revealed significant differences across plant species, reported using uppercase letters, but no differences across sites.

in November, when soil moisture was uniformly high for all samples (averaging $81 \pm 1 \%$ ). Soils at James were generally wetter than soils at Rice, and both sites had higher moisture in November $(74 \pm 2)$ than June $(57 \pm 2)$.

Soil redox potential $(\mathrm{mV})$ was typically higher for Juncus (group means ranged from 210 to 321, excluding NovJames) except in November at the James site where redox values, like soil moisture values, did not differ significantly. Redox potential was consistently higher at Rice $(68 \pm 26)$ compared to James $(23 \pm 16)$, though the sites were not significantly different for either month.

In November, there were no differences in $\mathrm{pH}$ across plant species, but $\mathrm{pH}$ was slightly higher at Rice (overall mean and standard error: $7.2 \pm 0.2)$ compared to James (6.0 $\pm 0.0)$. In June, the pattern was reversed. $\mathrm{pH}$ was consistently higher at James, and there were also differences in $\mathrm{pH}$ across the plant species. Means for the unvegetated soil were $\sim 1$ unit lower than the rhizosphere soils.

Irrespective of sampling date and plant type, the overall mean for OM (\%) was higher at James $(20 \pm 1)$ than Rice (14 $\pm 1)$. Values were $\sim 5 \%$ higher during plant senescence in November for both sites. Values for Juncus were lowest regardless of the site or date. Organic matter quality as assessed by $\mathrm{C}: \mathrm{N}$ was fairly consistent throughout the experiment $(14.7 \pm 0.2)$. Values associated with Typha were always the lowest (group means ranged from 12.4 to 13.8) though not significantly different from the unvegetated soil (13.2-15.7). Similarly, values for Juncus were generally the highest (15.5-19.4), and this distinction was especially noticeable in June.

3.5. Multiple Regression Analysis. The environmental data were relatively poor predictors of bacteria and denitrifier abundance in November. For both datasets, a significant multiple regression model could be created using $\mathrm{pH}$ and $\mathrm{C}$ : $\mathrm{N}$, but the amount of variance explained was low $(\mathrm{df}=31$; bacteria: $\operatorname{adj}-R^{2}=0.17, p=0.03$; denitrifiers: adj- $R^{2}=0.18$, $p=0.02)$. This is in sharp contrast to June, when the environmental data were excellent predictors of microbial abundance. For both bacteria and denitrifier abundance, the best model included a positive relationship with $\mathrm{pH}$ and $\mathrm{OM}$ and a negative correlation with soil moisture. The adjusted $R^{2}$ values for this data set were considerably higher: 0.81 and 0.86 for bacteria and denitrifiers, respectively (both $p<0.001)$. 


\section{Discussion}

The influence of plant species on rhizosphere soil conditions has been well documented (e.g., Lamers et al. [42], Grayston et al. [11], and Bodelier et al. [43]); however, corresponding effects on the soil microbial community remain understudied. In this research, we examined two microbial groups, total bacteria (via $16 S$ rRNA gene) and denitrifiers (via nirS), and found them to be variably distributed across the rhizosphere and rhizoplane microhabitats of three wetland macrophyte species. We found the effect to differ based on site, which is consistent with prior research that there is a synergistic relationship between plant species and soil type that shapes microbial abundance in the rhizosphere $[5,44-46]$. The physical-chemical properties of the native soil can be important directly via their impact on the microbial community or indirectly via the selective pressure they exert that determines which plants are successful in certain areas $[47,48]$.

4.1. Plant Species Effects. For both sites and dates, the abundance of bacteria was lowest in the unvegetated soil. Abundance was usually higher in the rhizosphere samples, but no consistent differences were observed across the macrophyte species. Plant-effect ratios indicate little-to-no rhizosphere enhancement during November and only a modest effect ( 1.5-fold increase) in June (Figure 2(a)). Moreover, the plant-effect ratio did not differ significantly based on the plant type. In contrast, enrichment for denitrifiers was more pronounced and varied across plant species. The rhizosphere associated with Typha and Peltandra had a significantly greater abundance of nirS denitrifiers compared to Juncus. This pattern followed expectations of ROL associated with each plant. In addition, the finding of an especially strong rhizosphere effect for Typha suggests a greater change in microenvironmental conditions occurs near the roots of this plant, relative to the other plant types studied. In fact, Typha was usually found in the wetter areas of the marsh and has the greatest expected levels of ROL, which would set up a strong gradient in environmental conditions associated with the rhizosphere.

The plant-soil continuum is a complex and heterogeneous environment, and high spatial variation shapes the microbial community that exists within the matrix. Typically, the rhizoplane is thought to be the epicenter of soil microbial activity due to high nutrient availability $[49,50]$. In this study, the bacterial abundance in the rhizoplane was greater when compared to the rhizosphere or bulk soil (Figure 3(a)). In contrast, nirS denitrifiers did not show increased abundance in the rhizoplane.

4.2. Season and Site Effects. In general, microbial abundance estimates were higher in November than in June. This increase is coincident with increased litter availability [51] and root senescence, which could both provide a source of fresh $\mathrm{OM}$ to fuel microbial growth. Our results are consistent with previous findings examining annual dynamics of denitrification and soil carbon pools [51-53]. While greater abundances were observed in November, plant-effect ratios were greatest in June. For example, we saw few rhizosphere plant effects for bacteria in November, but a significant increase in abundance for all three plant species at both sites in June (i.e., five out of six plant-effect ratios were significantly greater than one) (Figure 2). For denitrifiers, plant effects were evident for both sampling events, but they were much larger in June. The increased importance of vegetation during June may be due, at least in part, to the increase in plant activity during the growing season. During this time, we expect higher rates of photosynthesis, rhizodeposition, and ROL. These stimuli effectively increase plant effects in the rhizosphere compared to bulk soils.

The wetland plant species considered in this study varied in terms of aboveground and root biomass and foliar $\mathrm{C}: \mathrm{N}$ content, but these parameters did not change across sites. However, the sites did differ with respect to soil physicalchemical properties. Specifically, soil moisture was higher at James, as was OM content (Table 1). For other properties (redox, $\mathrm{pH}$, and $\mathrm{C}: \mathrm{N}$ ), within-site variation due to plant type was greater than differences across sites. The difference in OM observed between the two study sites most likely has to do with the site history. In particular, clear-cutting of the forested wetland at Rice prior to dam construction in 1920 removed a great deal of organic carbon, and the accumulation of sediments and OM decreased during impoundment. In contrast to Rice, the site at James is relatively undisturbed, although the surrounding areas were logged during the 1970s-1980s.

With regards to microbiology, differences across sites were apparent, especially in June. Both total bacterial abundance and nirS denitrifier abundance were higher at James than Rice. Moreover, we observed a difference in nirS plant effect ratios based on the site (Figure 2(b)) and documented a greater effect of plants at Rice. One possible explanation for this relates back to $\mathrm{OM}$ availability. In wetlands with lower OM reserves, such as Rice, plant exudates may be a more important source of carbon and energy to the bacterial community; thus, macrophyte effects may be greater. Microorganisms in the soils at James, with its consistently higher OM, may be less reliant on these root exudates.

4.3. Relationship with Soil Properties. Multiple regression analysis was applied to determine which attributes of the soil environment were good predictors of microbial abundance for each sampling event. In June, a model including soil moisture, and $\mathrm{pH}, \mathrm{OM}$ content allowed us to explain $81 \%$ and $86 \%$ of the variation in bacterial and nirs denitrifier abundance, respectively. This finding is consistent with our assertion that soil OM is more limiting during June and that root exudates are an important component of the resource pool at this time. The inclusion of $\mathrm{pH}$ in the model could be interpreted as a reflection of root activity. Root exudates can alter soil $\mathrm{pH}$ by releasing low molecular weight organic acids and alcohols [54] or by releasing hydrogen or bicarbonate ions [55]. The latter is more likely to have occurred in the soils examined in this study, as the rhizosphere $\mathrm{pH}$ tended to 
be greater than the reference soil $\mathrm{pH}$. Regardless of what is causing the $\mathrm{pH}$ fluctuations, our identification of $\mathrm{pH}$ as a key driver of the microbial community is consistent with several recent studies across diverse ecosystems [40, 56, 57]. When the data for November are considered, a different suite of predictors are important. In particular, we see $\mathrm{C}: \mathrm{N}$ emerge in the model for both the bacterial and nirS denitrifying community. This makes sense if we hypothesize that the quality of the native soil OM (i.e., C:N) will be more important at this time of year when root activity is less. This effect could be especially important as plant litter accumulates in the soil because the $\mathrm{C}: \mathrm{N}$ content of the vegetation differed by plant species (Table 2). Interestingly, the variance explained by the multiple regression models was much lower for November (17 and 18\% for bacteria and nirS denitrifiers, respectively) compared to June and indicates other environmental factors not considered in this study may be more important drivers of abundance. For example, if abundance at this time is largely affected by senescing resource inputs from plants, as hypothesized above, variations in the timing and intensity of these inputs across plant species may be an important factor that is not well captured by our sampling design. These pulses of inputs have been shown to be the major determinant of seasonal variation of soil microbial biomass [58], with different plant types and species demonstrating different responses to temporal variation.

\section{Conclusions}

Wetland plant species were found to have varying abundances of nirS denitrifying bacteria in their rhizospheres. Unvegetated reference soils always had the lowest abundances followed by Juncus and Peltandra, with Typha consistently having the highest abundances. Peltandra's and Typha's higher abundance of nirS denitrifying bacteria could be a result of a combination of soil conditions, ROL associated with the various root morphologies, and differences in root exudation. With regards to the total bacterial community, only a modest rhizosphere effect was detected, and it did not differ across plant species. For both microbial groups, plant effects were greater in June compared to November, most likely due to higher activity associated with the growing season. These stimuli effectively increase plant effects in the rhizosphere compared to bulk soils. Analysis of site effects revealed a stronger influence of plants at the younger, recently restored wetland; we hypothesize that this may be due to site history and/or differences in the standing stock of soil organic matter. Collectively, our results show that microbial abundance in the rhizosphere may be determined by a synergistic relationship between plant species and soil conditions. These findings have implications for our understanding of plant-microbe relationships in saturated soils and contribute to a growing appreciation of how this relationship may impact ecosystem biogeochemistry. Moreover, the work may be of interest to applied scientists interested in engineering wetland systems, as our results suggest that the effects of plant community composition can be mediated through microbial responses.

\section{Data Availability}

All of the original data related to the current study are available from the corresponding author upon request.

\section{Conflicts of Interest}

The authors declare that there are no conflicts of interest regarding the publication of this paper.

\section{Acknowledgments}

This research was funded in part by the Undergraduate Research Opportunities Program (UROP) Summer Fellowship from Virginia Commonwealth University as well as the VCU Rice Rivers Center Student Research Grant, both to Morina. Thanks to Jamie Gillespie, David Berrier, Rana Mehr, Aaron Porter, and Nicki Dadashian for their assistance in the field and in the lab. Thanks to Chansotheary Dang for her edits in this manuscript. We would like to acknowledge Cyrus Brame with the James River National Wildlife Refuge for assistance with site access. This study was supported in part by the VCU Rice Rivers Center (Publication \# 86).

\section{References}

[1] J. N. Galloway, E. B. Cowling, S. J. Seitzinger, and R. Socolow, "Reactive nitrogen: too much of a good thing?," AMBIO: A Journal of the Human Environment, vol. 31, no. 2, pp. 60-63, 2002.

[2] S. J. Jordan, J. Stoffer, and J. A. Nestlerode, "Wetlands as sinks for reactive nitrogen at continental and global scales: a metaanalysis," Ecosystems, vol. 14, no. 1, pp. 144-155, 2011.

[3] K. R. Reddy and R. D. DeLaune, Biogeochemistry of Wetlands: Science and Applications, CRC Press, Boca Raton, FL, USA, 2008.

[4] A. E. Sutton-Grier, J. P. Wright, B. M. McGill, and C. Richardson, "Environmental conditions influence the plant functional diversity effect on potential denitrification," PLoS One, vol. 6, pp. 1-9, 2011.

[5] D. A. Wardle, Communities and Ecosystems: Linking the Aboveground and Belowground Components, Princeton University Press, Princeton, NJ, USA, 2002.

[6] L. Windham and L. A. Meyerson, "Effects of common reed (Phragmites australis) expansions on nitrogen dynamics of tidal marshes of the Northeastern U.S.," Estuaries, vol. 26, no. 2, pp. 452-464, 2003.

[7] M. Alldred and S. B. Baines, "Effects of wetland plants on denitrification rates: a meta-analysis," Ecological Applications, vol. 26, no. 3, pp. 676-685, 2016.

[8] S. C. Neubauer, K. Givler, S. K. Valentine, and J. P. Megonigal, "Seasonal patterns and plant-mediated controls of subsurface wetland biogeochemistry," Ecology, vol. 86, no. 12, pp. 3334-3344, 2005.

[9] L. Philippot, S. Hallin, G. Börjesson, and E. M. Baggs, "Biochemical cycling in the rhizosphere having an impact on global change," Plant Soil, vol. 321, no. 1-2, pp. 61-81, 2009.

[10] S. J. Grayston, D. Vaughan, and D. Jones, "Rhizosphere carbon flow in trees, in comparison with annual plants: the importance of root exudation and its impact on microbial activity and nutrient availability," Applied Soil Ecology, vol. 5, no. 1, pp. 29-56, 1997. 
[11] S. J. Grayston, S. Wang, C. D. Campbell, and A. C. Edwards, "Selective influence of plant species on microbial diversity in the rhizosphere," Soil Biology and Biochemistry, vol. 30, no. 3, pp. 369-378, 1998.

[12] M. J. Brimecombe, F. A. De Leij, and J. M. Lynch, "The effect of root exudates on rhizosphere microbial populations," in The Rhizosphere, R. Pinto, Z. Varanini, and P. Nannipierei, Eds., p. 95, Marcel Dekker, New York, NY, USA, 2001.

[13] E. Somers, Vanderleyden, and M. Srinivisam, "Rhizosphere bacterial signaling: a love parade beneath our feet," Critical Reviews in Microbiology, vol. 30, no. 4, pp. 205-240, 2004.

[14] M. H. Chantigny, D. A. Angers, D. Prevost, L. P. Vezina, and F. P. Chalifour, "Soil aggregation and fungal and bacterial biomass under annual and perennial cropping systems," Soil Science Society of America Journal, vol. 61, no. 1, pp. 262-267, 1997.

[15] B. S. Griffiths, K. Ritz, N. Ebblewhite, and G. Dobson, "Soil microbial community structure: effects of substrate loading rates," Soil Biology and Biochemistry, vol. 31, no. 1, pp. 145$153,1998$.

[16] H. P. Bias, T. L. Weir, L. G. Perry, S. Gilroy, and J. M. Vivanco, "The role of root exudates and allelochemicals in the rhizosphere," Plant and Soil, vol. 256, no. 1, pp. 67-83, 2006.

[17] A. Neori, K. R. Reddy, H. Cisková-Koncolova, and M. Agami, "Bioactive chemicals and biological-biochemical activities and their functions in rhizospheres of wetland plants," The Botanical Review, vol. 66, no. 3, pp. 350-378, 2000.

[18] J. P. Zarnetske, R. Haggerty, S. M. Wondzell, and M. A. Baker, "Labile dissolved organic carbon supply limits hyporheic denitrification," Journal of Geophysical Research, vol. 116, pp. 1-16, 2011.

[19] M. Spohn, A. Ermak, and Y. Kuzvakov, "Microbial gross organic phosphorus mineralization can be stimulated by root exudates - a P-33 isotopic dilution study," Soil Biology and Biochemistry, vol. 65, pp. 245-263, 2013.

[20] X. Zhai, N. Piwpuan, C. A. Arias, T. Headley, and H. Brix, "Can root exudates from emergent wetland plants fuel denitrification in subsurface flow constructed wetland systems?," Ecological Engineering, vol. 61, pp. 555-563, 2013.

[21] J. Sérandour, S. Reynaud, J. Willison et al., "Ubiquitous watersoluble molecules in aquatic plant exudates determine specific insect attraction," PLoS One, vol. 3, no. 10, Article ID e3350, 2008.

[22] A. Mucha, C. Almeida, A. Bordalo, and M. Vasconcelos, "LMWOA (low molecular weight organic acid) exudation by salt marsh plants: natural variation and response to $\mathrm{Cu}$ contamination," Estuarine Coastal and Shelf Science, vol. 88, no. 1, pp. 63-70, 2010.

[23] A. S. Sutton-Grier and J. P. Megonigal, "Plant species traits regulate methane production in freshwater wetland soils," Soil Biology and Biochemistry, vol. 43, no. 2, pp. 413-420, 2011.

[24] J. M. Smith, A. C. Mosier, and C. A. Francis, "Spatiotemporal relationships between the abundance, distribution, and potential activities of ammonia-oxidizing and denitrifying microorganisms in intertidal sediments," Microbial Ecology, vol. 69, no. 1, pp. 13-24, 2015.

[25] L. Philippot, "Denitrifying genes in bacterial and archaeal genomes," Biochimica et Biophysica Acta (BBA) - Gene Structure and Expression, vol. 1577, no. 3, pp. 355-376, 2002.

[26] I. N. Throbäck, K. Enwall, A. Jarvis, and S. Hallin, "Reassessing PCR primers targeting nirS, nirK and nos $Z$ genes for community surveys of denitrifying bacteria with DGGE," FEMS Microbiology Ecology, vol. 49, no. 3, pp. 401-417, 2004.

[27] S. Sharma, Z. Szele, R. Schilling, J. C. Munch, and M. Schloter, "Influence of freeze-thaw stress on the structure and function of microbial communities and denitrifying populations in soil," Applied and Environmental Microbiology, vol. 72, no. 3, pp. 2148-2154, 2006.

[28] C. J. Smith, F. L. Dong, J. Wilson, A. Stott, A. M. Osborn, and D. B. Nedwell, "Seasonal variation in denitrification and dissimilatory nitrate reduction to ammonium process rates and corresponding key functional genes along an estuarine nitrate gradient," Frontiers in Microbiology, vol. 6, 2015.

[29] K. Xue, L. Wu, Y. Deng et al., "Functional gene differences in soil microbial communities from conventional, low-input, and organic farmlands," Applied and Environmental Microbiology, vol. 79, no. 4, pp. 1284-1292, 2013.

[30] M. Yoshida, I. Satoshi, S. Otsuka, and K. Senoo, "Temporal shifts in diversity and quantity of nirS and nirK in a rice paddy field soil," Soil Biology and Biogeochemistry, vol. 41, no. 10, pp. 2044-2051, 2009.

[31] Y. N. Chen, W. Zhou, Y. P. Li et al., "Nitrite reductase genes as functional markers to investigate diversity of denitrifying bacteria during agricultural waste composting," Applied Microbiology and Biotechnology, vol. 98, no. 9, pp. 4233-4243, 2014.

[32] D. H. Graf, C. M. Jones, and S. Hallin, "Intergenomic comparisons highlight modularity of the denitrification pathway and underpin the importance of community structure for $\mathrm{N} 2 \mathrm{O}$ emissions," PLoS One, vol. 9, no. 12, Article ID e114118, 2014.

[33] R. B. Franklin, E. M. Morrissey, and J. C. Morina, "Changes in abundance and community structure of nitrate-reducing bacteria along a salinity gradient in tidal wetlands," Pedobiologia, vol. 60, pp. 21-26, 2017.

[34] A. Henneberg, B. K. Sorrell, and H. Brix, "Internal methane transport through Juncus effusus: experimental manipulation of morphological barriers to test above- and below-ground diffusion limitation," New Phytologist, vol. 196, no. 3, pp. 799-806, 2012.

[35] J. P. Frye, A. L. Mills, and W. E. Odum, "Methane flux in Peltandra virginica (Araceae) wetlands: comparison of field data with a mathematical model," American Journal of Botany, vol. 81, no. 4, pp. 407-413, 1994.

[36] T. Tornberg, M. Bendix, and H. Brix, "Internal gas transport in Typha latifolia L. and Typha angustifolia L. 2. Convective throughflow pathways and ecological significance," Aquatic Botany, vol. 49, no. 2-3, pp. 91-105, 1994.

[37] H. Laanbroek, "Methane emission from natural wetlands: interplay between emergent macrophytes and soil microbial processes. A mini-review," Annals of Botany, vol. 105, no. 1, pp. 141-153, 2010

[38] A. Wießner, P. Kuschk, and U. Stottmeister, "Oxygen release by roots of Typha latifolia and Juncus effusus in laboratory hydroponic systems," Acta Biotechnologica, vol. 22, no. 1-2, pp. 209-216, 2002.

[39] L. A. Phillips, S. A. Armstrong, J. V. Headley, C. W. Greer, and J. J. Germida, "Shifts in root-associated microbial communities of Typha latifolia growing in naphthenic acids and relationship to plant health," International Journal of Phytoremediation, vol. 12, no. 8, pp. 745-60, 2010.

[40] N. Fierer, J. A. Jackson, R. Vilgalys, and R. B. Jackson, "Assessment of soil microbial community structure by use of taxon-specific quantitative PCR assays," Applied and Environmental Microbiology, vol. 71, no. 7, pp. 4117-4120, 2005. 
[41] A. C. Mosier and C. A. Francis, "Denitrifier abundance and activity across the san Francisco Bay estuary," Environmental Microbiology Reports, vol. 2, no. 5, pp. 667-676, 2010.

[42] L. P. M. Lamers, J. M. H. van Diggelen, H. J. M. Op den Camp et al., "Microbial transformations of nitrogen, sulfur, and iron dictate vegetation composition in wetlands: a review," Frontiers in Microbiology, vol. 3, pp. 1-12, 2012.

[43] P. L. E. Bodelier, P. Frenzel, H. L. Drake et al., "Ecological aspects of microbes and microbial communities inhabiting the rhizosphere of wetland plants," in Wetlands and natural resource management, J. T. A. Verhoeven, B. Beltman, R. Bobbink, and D. F. Whigham, Eds., Springer, Berlin, Germany, pp. 205-238, 2006.

[44] N. Nunan, T. J. Daniell, B. K. Singh, A. Papert, J. W. McNicol, and J. L. Prosser, "Links between plant and rhizoplane bacterial communities in grassland soils," Applied and Environmental Microbiology, vol. 71, no. 11, pp. 6784-6792, 2005.

[45] G. Berg, "Plant-microbe interactions promoting plant growth and health: perspectives for controlled use of microorganisms in agriculture," Journal of Applied Microbiology and Biotechnology, vol. 71, pp. 4203-4213, 2009.

[46] W. Cheng, D. W. Johnson, and S. Fu, "Rhizosphere effects on decomposition: controls of plant species, phenology, and fertilization," Soil Science Society of America Journal, vol. 67, no. 5, pp. 1418-1427, 2003.

[47] M. S. Girvan, J. Bullimore, J. N. Pretty, A. M. Osborn, and A. S. Ball, "Soil type is the primary determinant of the composition of the total and active bacterial communities in arable soils," Applied and Environmental Microbiology, vol. 69, no. 3, pp. 1800-1809, 2003.

[48] J. N. Boyer and P. M. Groffman, "Bioavailability of water extractable organic carbon fractions in forest and agricultural soil profiles," Soil Biology and Biogeochemistry, vol. 28, no. 6, pp. 783-790, 1996.

[49] P. R. Darrah, "The rhizosphere and plant nutrition: a quantitative approach," Plant and Soil, vol. 155-156, pp. 1-20, 1993.

[50] J. M. Lynch and J. M. Whipps, "Substrate flow in the rhizosphere," Plant and Soil, vol. 129, no. 1, pp. 1-10, 1990.

[51] S. K. Bastviken, P. G. Eriksson, A. Ekstrom, and K. Tonderski, "Seasonal denitrification potential in wetland sediments with organic matter from different plant species," Water, Air, and Soil Pollution, vol. 183, no. 1-4, pp. 25-35, 2007.

[52] A. Thorén, C. Legrand, and K. S. Tonderski, "Temporal export of nitrogen from a constructed wetland: influence of hydrology and senescing submerged plants," Ecological Engineering, vol. 23, no. 4-5, pp. 233-249, 2004.

[53] M. B. Lavigne, R. J. Foster, and G. Goodine, "Seasonal and annual changes in soil respiration in relation to soil temperature, water potential and trenching," Tree Physiology, vol. 24, no. 4, pp. 415-424, 2004.

[54] A. Mucha, C. Almeida, A. Bordalo, and M. Vasconcelos, "Exudation of organic acids by a marsh plant and implications on trace metal availability in the rhizosphere of estuarine sediments," Estuarine Coastal and Shelf Science, vol. 65, no. 12, pp. 191-198, 2005.

[55] P. B. Tinker and P. Nye, Solute Movement in the Rhizosphere, Oxford University Press, Oxford, UK, 2000.

[56] H. Serna-Chavez, N. Fierer, and P. M. van Bodegom, "Global drivers and patterns of microbial abundance in soil," Global Ecology and Biogeography, vol. 22, no. 10, pp. 1162-1172, 2013.
[57] W. H. Hartman, C. J. Richardson, R. Vigalys, and G. L. Bruland, "Environmental and anthropogenic controls over bacterial communities in wetland soils," Proceedings of the National Academy of Sciences U.S.A., vol. 105, no. 46, pp. 17842-17847, 2008.

[58] D. A. Wardle, "A comparative assessment of factors which influence microbial biomass carbon and nitrogen levels in soils," Biological Reviews, vol. 67, no. 3, pp. 321-358, 1992. 

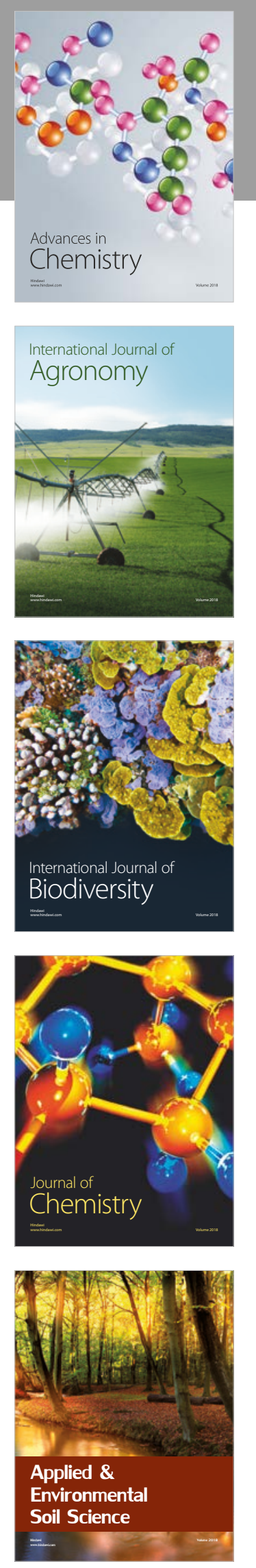

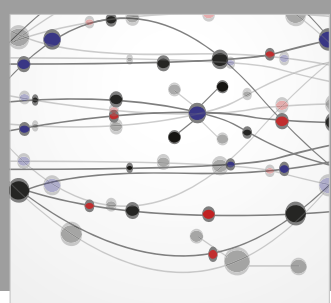

The Scientific World Journal

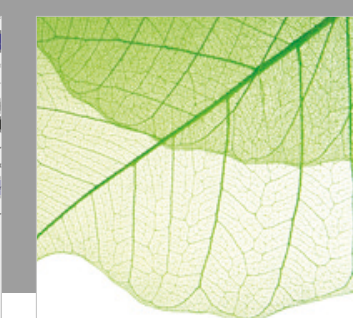

Journal of Botany

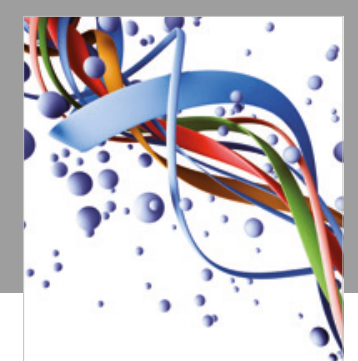

Scientifica

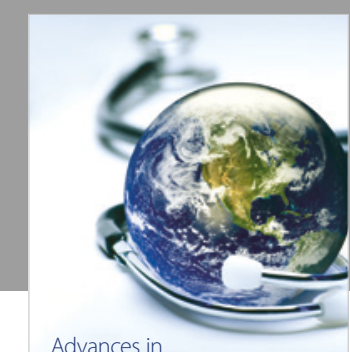

Public Health

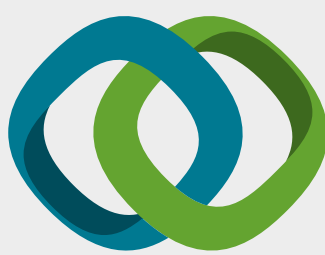

Hindawi

Submit your manuscripts at

www.hindawi.com
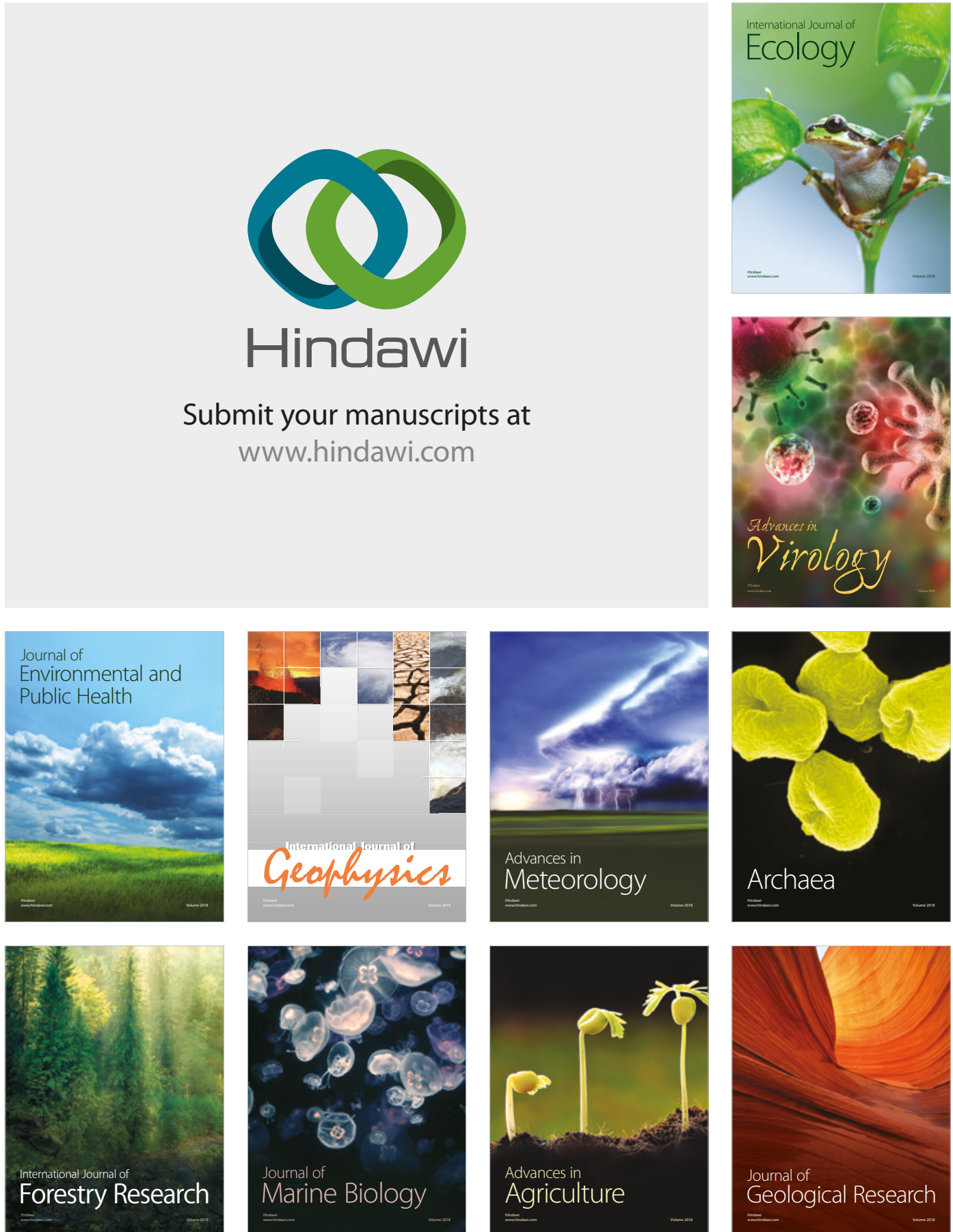

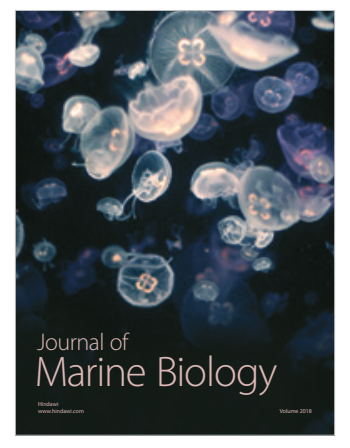

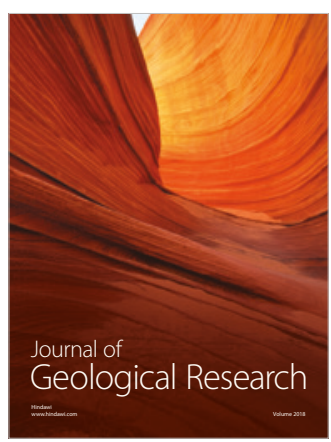

